\title{
Partisipasi Anggota Kelompok Tani dalam Berusahatani Bawang Putih di Desa Sallu Kecamatan Miomaffo Barat Kabupaten Timor Tengah Utara
}

\author{
Marsianus Falo ${ }^{\mathrm{a}}$, Agustinus Nubatonis ${ }^{\mathrm{b}}$ \\ ${ }^{a}$ Fakultas Pertanian, Universitas Timor, Kefamenanu, TTU - NTT, Indonesia. \\ ${ }^{b}$ Fakultas Pertanian, Universitas Timor, Kefamenanu, TTU - NTT, Indonesia.
}

\section{Article Info}

Article history:

Received 18 Februari 2017

Received in revised form 20 Maret 2017

Accepted 31 Maret 2017

\section{Keywords:}

Bawang Putih

Kelompok Tani

Partisipasi

\section{Abstrak}

Penelitian ini bertujuan untuk mengetahui karakteristik, tingkat partisipasi dan hambatan-hambatan partisipasi anggota kelompok tani bawang putih di Desa Sallu Kecamatan Miomaffo Barat Kabupaten Timor Tengah Utara. Metode penelitian menggunakan metode survey dan pengumpulan data meliputi data primer dan data sekunder. Analisis data digunakan Skala likert. Hasil penelitian menunjukkan 1) karakteristik anggota kelompok tani bawang putih memiliki potensi yang layak dikembangkan produktivitasnya yakni umur, pendidikan formal, pengalaman berusahatani bawang putih, jumlah anggota keluarga, luas lahan garapan, dan kelembagaan kelompok taninya; 2) tingkat partisipasi dari 95 responden anggota kelompok tani berada dalam kategori 3 yakni "Kadang-kadang" dengan nilai skor rata-rata tingkat partisipasi kelompok tani dari 5 indikator penilaian adalah 63,6; dan 3) kendala-kendala dalam berusahatani bawang putih: kurang bibit bawang putih yang unggul, akses informasi harga pasar, pola usahatani bawang putih masih tradisional, pelatihan budidaya bawang putih, iklim yang kurang bersahabat, usaha bawang putih semakin sempit, kurangnya modal usaha. (02017 dipublikasikan oleh Agrimor.

\section{Pendahuluan}

Tujuan pembangunan nasional ditujukan untuk meningkatkan pendapatan dan kesejahteraan masyarakat, salah satunya melalui pembangunan pertanian. Hal ini sesuai kondisi negara Indonesia yang merupakan negara agraris dan sebagian besar penduduknya bermata pencaharian dari bercocok tanam (Ken Suratiyah, 2015). Pembangunan pertanian ke depan diharapkan dapa memberikan kontribusi yang lebih besar dalam rangka mengurangi kesenjangan dan memperluas kesempatan kerja, serta mampu memanfaatkan peluang ekonomi yang terjadi sebagai dampak dari globalisasi dan liberalisasi ekonom dunia, untuk itu diperlukan sumberdaya manusia pertanian yang berkualitas dan handal, dengan memiliki ciri adanya kemandirian, professionalitas, berjiwa wirausaha (entrepreneurship), berdedikasi, etos kerja yang tinggi, disiplin dan moral yang luhur serta berwawasan global. Dengan demikian petani dan pelaku usaha pertanian lainnya akan mampu membangun usahatani yang berdaya guna dan berdaya saing, salah satunya melalui kegiatan penyuluhan pertanian.

Kegiatan penyuluhan agar efektif maka dapat dibentuk kelompok-kelompok tani yang diharapkan berfungsi sebagai wadah yang dapat memotivasi petan sebagai anggotanya untuk lebih aktif dan berperan dalam berbagai kegiatan guna mengembangkan dan meningkatkan usahataninya. Pembinaan usahatani melalui kelompok tani sebagai upaya percepatan sasaran yaitu petani yang banyak jumlahnya dan kawasan pedesaan yang tersebar dan luas, sehingga dalam pembinaan kelompok diharapkan tumbuh wawasan kebersamaan memecahkan dan merubah citra usahatani sekarang menjadi usahatani masa depan yang cerah Tujuan dibentuknya kelompok tani adalah meningkatkan dan mengembangkan kemampuan petani dan keluarganya sebagai subjek pendekatan kelompok, aga lebih berperan dalam pembangunan. Aktivitas usahatani yang lebih baik dapa dilihat dari adanya peningkatan dalam produktivitas usahatani sehingga akan meningkatkan pendapatan petani dan terciptanya kesejahteraan bagi petani dan keluarganya. Keberadaan kelompok tani diharapkan dapat memfasilitas antara petani dengan program penyuluhan pertanian yang selaras tujuannya yaitu peningkatan pendapatan dan kesejahteraan petani. Oleh karena itu pembinaan kelompok tani perlu dilaksanakan secara lebih intensif, terarah dan terencana sehingga mampu meningkatkan peran dan fungsinya.

Peranan kelompok tani akan semakin meningkat apabila dapa menumbuhkan kekuatan-kekuatan yang dimiliki dalam kelompok itu sendir untuk menggerakkan dan mendorong perilaku anggotanya ke arah pencapaian tujuan kelompok sehingga kelompok tani akan berkembang menjadi lebih dinamis kondisi ini harus didukung oleh seluruh kegiatan yang meliputi inisiatif daya kreasi dan tindakan-tindakan nyata yang dilakukan oleh pengurus dan anggota kelompok tani dalam melaksanakan rencana kerja anggota kelompok yang telah disepakati bersama. Dinamika anggota kelompok tani merupakan gerakan bersama yang dilakukan secara serentak dan bersamaan dalam melaksanakan seluruh kegiatan anggota kelompok tani dalam mencapai tujuannya, yaitu peningkatan hasil produksi dan mutunya untuk meningkatkan pendapatan mereka (Ban, 1999).

Desa Sallu, terdapat 6 (enam) kelompok tani pemula yaitu, kelompok tani Tafen'tob, Oel'nasi, KWT Melati, KWT Monit'tabua, Nek'ana, Ai'nun. Kelompok tani tersebut terdiri dari pengurus dan anggota kelompok. Kegiatan usahatani yang dikembangkan adalah tanaman jagung, sayur-sayuran, bawang putih dan bawang merah, padi sawah serta padi ladang. Bawang putih merupakan tanaman hortikultura yang banyak dibutuhkan terutama dalam peranannya sebagai penambah cita rasa makanan dan bumbu masak berbagai macam makanan, bawang putih juga digunakan sebagai obat-obatan berbagai penyakit seperti tekanan darah tinggi, sakit kepala dan menurunkan kada kolesterol.

Kabupaten TTU (Timor Tengah Utara) yang berada di Provinsi NTT (Nusa Tenggara Timur) terus menggalakkan usahatani bawang putih pada daerah daerah yang berpotensi, salah satunya adalah Kecamatan Miomaffo Barat Kecamatan Miomaffo Barat memiliki spesifikasi yang cocok untuk pertumbuhan tanaman bawang putih seperti ketinggian $700-1100 \mathrm{mdpl}$, suhu rata-rata $20^{\circ} \mathrm{C}$ $25^{\circ} \mathrm{C}$, curah hujan rata-rata $1200-2400 \mathrm{~mm}$ per tahun serta tekstur tanah yang gembur dan subur). Bagi masyarakatnya, usahatani bawang putih telah dilakukan secara turun-temurun. Tingkat produksi bawang putih di Kecamatan Miomaffo Barat berfluktuasi (BPS Kab. TTU, 2015), penyebabnya antara lain; keadaan iklim khususnya curah hujan yang tidak menentu, luasan areal tanam dan luas panen. Kondisi ini mengakibatkan produksi bawang putih lokal belum mampu memenuhi permintaan bawang putih masyarakat di Kabupaten TTU sehingga harus diimpor dari luar (survei awal).

Hasil observasi yang dilakukan untuk mengetahui preferensi masyarakat terhadap bawang putih di pasar baru dan pasar lama Kefamenanu antara bawang lokal dan bawang impor, ternyata minat masyarakat terhadap bawang putih lokal dan bawang putih impor itu sama. Hal ini menunjukkan bahwa bawang putih lokal cukup bersaing dengan bawang putih impor di pasaran. Agar kontinuitas ketersediaan bawang putih lokal tetap terjadi maka harus didukung oleh berbagai faktor seperti; ketersediaan sarana produksi pertanian, kegiatan usahatani bawang putih yang intensif, perluasan areal tanam, penggunaan bibit unggul, penggunaan tenaga kerja yang terampil dan saluran distribusi terhadap produk yang jelas. Pendapatan petani dapat meningkat jika dilakukan pengembangan usahatani bawang putih yang bersifat komersial dengan memperhatikan strategistrategi pengembangan mulai dari proses pembudidayaan hingga proses pemasaran guna meningkatkan pendapatan petani.

Program pembangunan di Kabupaten TTU sepenuhnya diserahkan kepada pihak penyuluh lapangan dan dana telah disediakan oleh pemerintah Kabupaten TTU. Penyuluh bertugas untuk merencanakan programa-programa pertanian yang akan diterapkan dimasyarakat, sehingga untuk menyukseskan kegiatan tersebut perlu adanya partisipasi masyarakat serta kelompok tani yang ada di Desa Sallu. Kelompok tani di Desa Sallu bukan merupakan kelompok mandiri karena masih membutuhkan pendampingan penyuluh. Hal ini terkendala karena anggota kelompok tani belum sadar untuk melakukan semua kegiatan usahatani bawang putih yang sudah di programkan dengan baik dan partisipasi anggota yang kurang optimal dalam kegiatan tersebut (kegiatan fisik pemilihan bibit, pengolahan lahan, penanaman, pemupukan, pengairan, pengendalian, panen, pasca panen dan pemasaran).

\section{Metode}

\subsection{Waktu dan Lokasi Penelitian}

Penelitian dilaksanakan dari bulan Mei sampai dengan bulan Oktober 2016. Lokasi penelitian berada di Kelurahan Sallu Kecamatan Miomaffo Barat Kabupaten TTU.

\subsection{Metode Pengambilan Data}

Metode penelitian yang digunakan adalah metode survei. Data yang diperlukan meliputi data primer dan data sekunder. Data primer diperoleh melalui observasi langsung ke lokasi penelitian dan mengadakan wawancara langsung dengan responden (menggunakan daftar pertanyaan/kuesioner). Data sekunder diperoleh dari studi kepustakaan, laporan tahunan atau data statistik bulanan yang terkait meliputi Dinas Pertanian yaitu Balai Penyuluhan Pertanian Lapangan, serta sumber-sumber lain yang mendukung penelitian ini.

\subsection{Metode Pengambilan Sampel}

Kelurahan Sallu, Kecamatan Miomaffo Barat, Kabupaten TTU terdapat enam (6) kelompok tani yang berbadan hukum dan berusahatani tanaman bawang putih. Adapun nama-nama kelompok tani tersebut adalah: Kelompok Tani Tafen'tob dengan anggota 15 orang, Kelompok tani Oel'nasi dengan anggota 16 orang, Kelompok tani Nek'ana dengan anggota 14 orang, Kelompok Tani Ai'nun dengan anggota 15 orang, Kelompok Wanita Tani Melati dengan anggota 18 orang, Kelompok tani Monitabua dengan anggota 17 orang. Total anggota dari ke enam kelompok tani yaitu 95 orang, sehingga sampel dilakukan secara sensus. 


\subsection{Pengamatan dan Konsep Pengukuran}

Secara operasional pengamatan dan konsep pengukuran dapat dijabarkan sebagai berikut:

- Partisipasi adalah keterlibatan atau keikutsertaan anggota kelompok tani dalam pelaksanaan kegiatan usahatani bawang putih dengan cara menghadiri rapat-rapat penyuluhan, mendemonstrasikan metode baru untuk usahatani.

- Anggota kelompok tani adalah kumpulan petani yang terikat secara non formal, seperti sosial, ekonomi, sumber daya, keakraban, dan kepentingan bersama dan saling percaya, serta mempunyai pimpinan untuk mencapai tujuan bersama.

- Program usahatani bawang putih penyuluhan adalah programa yang disusun oleh penyuluh pertanian bersama petani untuk wilayah kerja, mengenai kegiatan usahatani bawang putih.

- Penyuluh pertanian lapangan (PPL) adalah mediator bagi petani untuk mendapatkan informasi serta pengetahuan

\subsection{Metode Analisis Data}

Partisipasi anggota kelompok tani dalam berusahatani bawang putih Menggunakan metode Likert. Metode ini menjabarkan beberapa item pertanyaan yang disusun dalam kuesioner dan setiap pertanyaan diberi skor penilaian dengan pilihan responden (Balck \& Champion, 1992). Untuk mengukur tingkat partisipasi anggota kelompok tani dijabarkan dalam kuesioner dengan metode skoring (skala Likert), berikut ini tabel skor maksimum dan minimum tingkat partisipasi anggota kelompok tani.

Tabel 1. Skor Maksimum dan Minimum Partisipasi Anggota Kelompok Tani di Desa Sallu

\begin{tabular}{llcc}
\multicolumn{4}{c}{ Desa Sallu } \\
\hline No. & \multicolumn{1}{c}{$\begin{array}{c}\text { Tingkat Partisipasi Anggota } \\
\text { Kelompok Tani }\end{array}$} & $\begin{array}{c}\text { Skor } \\
\text { Minimum }\end{array}$ & $\begin{array}{c}\text { Skor } \\
\text { Maksimum }\end{array}$ \\
\hline 1. & $\begin{array}{l}\text { Partisipasi pada RAT } \\
\text { 2. }\end{array}$ & 4 & 20 \\
& $\begin{array}{l}\text { Partisipasi pada pertemuan dan } \\
\text { kegiatan KT }\end{array}$ & 4 & 20 \\
3. $\quad \begin{array}{l}\text { Partisipasi pada pembuatan program } \\
\text { penyuluhan usahatani bawang putih }\end{array}$ & 4 & 20 \\
4 & Kemampuan kinerja kelompok & 4 & 20 \\
\hline Jumlah & 16 & 80 \\
\hline
\end{tabular}

Sumber: Sugiyono, (2011)

Panjang interval kelas masing-masing tingkat partisipasi adalah:

Tabel 2. Interval Kelas dan Tingkat Partisipasi Anggota Kelompok Tani

\begin{tabular}{|c|c|c|c|c|}
\hline No & $\begin{array}{l}\text { Kategori Tingkat } \\
\text { Partisipasi }\end{array}$ & $\begin{array}{c}\text { Persentase } \\
\text { Pencapaian } \\
\text { Skor } \\
\text { Maksimum }\end{array}$ & Frekuensi & $\begin{array}{c}\text { Persentase } \\
(\%)\end{array}$ \\
\hline 1 & Sangat tidak aktif & $\geq 20-36$ & ............. & \\
\hline 2 & Tidak aktif & $>36-52$ & ............. & ............. \\
\hline 3 & Ragu-Ragu & $>52-68$ & ..... & \\
\hline 4 & Aktif & $>68-84$ & …….... & ............ \\
\hline 5 & Sangat Aktif & $>84-100$ & & \\
\hline \multicolumn{2}{|c|}{ Jumlah } & & $\sum \mathrm{Fr}$ & 100 \\
\hline
\end{tabular}

\section{Hasil dan Pembahasan}

\subsection{Keadaan Umum Lokasi Penelitian}

a. Letak Administrasi dan Luas Wilayah

Desa Sallu berada di wilayah administrasi Kecamatan Miomaffo Bara berjarak $\pm 30 \mathrm{~km}$ dari ibu kota Kabupaten Timor Tengah Utara dan $1 \mathrm{~km}$ dari ibu kota Kecamatan Miomaffo Barat. Batas Wilayah Desa Sallu meliputi: Sebelah Utara: Desa Batnes - Kelurahan Eban, Sebelah Selatan: Desa Lemon Desa Fatumnanu Kabupaten TTS, Sebelah Timur: Desa Noetoko - Desa Suanae, Sebelah Barat: Kelurahan Eban Kecamatan Miomaffo Barat. Berdasarkan data monografi Desa Sallu tahun 2014, hamparan wilayahnya heterogen yang terdiri dari pegunungan, bukit, dan persawahan.

\section{b. Keadaan Alam}

Keadaan topografi Desa Sallu berupa dataran sedikit lereng (daratan kering, bergelombang) dengan tekstur tanah aluvial terdapat di sekitar pekarangan, kebun dan lahan kering (ladang), tanah gambut terdapat di persawahan dengan $\mathrm{pH}$ tanah dominan 4-5 dengan tingkat kemasaman cukup tinggi dan iklim sub tropis.

\section{c. Keadaan Iklim}

Temperatur udara tertinggi berkisar antara $27{ }^{\circ} \mathrm{C}-30^{\circ} \mathrm{C}$ dan suhu terendah antara $18{ }^{\circ} \mathrm{C}-24{ }^{\circ} \mathrm{C}$, curah hujan rata-rata $250 \mathrm{~mm}$ per bulan dengan hari hujan rata-rata 10 hari per bulan. Curah hujan tertinggi biasanya pada bulan Desember, Januari, Februari, Maret, April, sedangkan bulan-bulan yang lain curah hujannya tergolong rendah sampai sekitar antara 60\%-80\%.

\section{d. Jumlah Penduduk dan Mata Pencaharian}

Hasil Sensus penduduk tahun 2014 terdapat jumlah penduduk 2.119 orang, yang terdiri atas yang terdiri dari ; laki-laki 1.141 jiwa dan perempuan 978 jiwa dengan jumlah kepala keluarga 556 KK. Jumlah penduduk berdasarkan mata pencaharian: petani 494 kk, pedagang 15 kk, PNS 48 kk, Purnabakti 3 kk, ABRI $3 \mathrm{kk}$.

e. Tingkat Pendidikan

Tingkatan Pendidikan di Kelurahan Sallu bervariasi dari yang belum pernah sekolah sampai yang tamat S1/Sederajat. Tingkat pendidikan yang paling banyak di Desa Sallu adalah tamat SLTP. Tingkat pendidikan di Kelurahan Sallu diuraikan dalam Tabel 3.

Tabel 3. Tingkat Pendidikan Penduduk Kelurahan Sallu Tahun 2016

\begin{tabular}{lcc}
\hline \multicolumn{1}{c}{ Tingkatan Pendidikan } & Jumlah (Orang) & Persentase (\%) \\
\hline Belum sekolah & 322 & 15,19 \\
Buta huruf & 91 & 4,29 \\
Tidak lulus SD & 250 & 11,79 \\
Lulus SD & 345 & 16,28 \\
Lulus SLTP & 457 & 21,56 \\
Lulus SLTA & 389 & 18,35 \\
Lulus Perguruan Tinggi & 265 & 12,51 \\
\hline Jumlah & 2119 & 100,00 \\
\hline
\end{tabular}

\subsection{Karakteristik Personal Anggota Kelompok Tani}

Karakteristik merupakan latar belakang keadaan dari responden sebagai tanggapan dan langkah selanjutnya dalam penelitian ini. Berdasarkan hasil wawancara yang dilakukan terhadap 95 responden di Desa Sallu Kecamatan Miomaffo Barat Kabupaten Timor Tengah Utara dengan menilai partisipasi anggota kelompok tani dalam berusahatani bawang putih serta pengamatan langsung di lokasi penelitian, maka diperoleh gambaran karakteristik responden sebagai berikut:

a. Umur

Umur sering diidentikkan dengan produktivitas seseorang karena tingkat umur dapat mempengaruhi aktivitas dan kreativitas kerja. Hasil penelitian menunjukkan bahwa umur responden bervariasi antara 27-67 tahun. Distribusi umur responden dapat dilihat dalam Tabel 4

Tabel 4. Distribusi Responden Berdasarkan Golongan Umur di Desa Sallu Kecamatan Miomaffo Barat Kabupaten Timor Tengah Utara, 2016.

\begin{tabular}{|c|c|c|}
\hline Kelompok Umur & $\begin{array}{l}\text { Jumlah } \\
\text { (Orang) }\end{array}$ & $\begin{array}{c}\text { Persentase } \\
(\%)\end{array}$ \\
\hline $25-34$ & 5 & 5,26 \\
\hline $35-44$ & 37 & 38.94 \\
\hline $45-54$ & 19 & 20,02 \\
\hline $55-64$ & 27 & 28,42 \\
\hline$>64$ & 7 & 7,36 \\
\hline & 95 & 100 \\
\hline
\end{tabular}

Berdasarkan Tabel 4. diketahui bahwa responden terbanyak pada golongan umur 35-44 tahun yakni sebanyak 37 orang dengan presentasi $38.94 \%$, sedangkan umur terendah berada kisaran umur 25-34 tahun yakni sebanyak 5 orang dan presentasinya sebesar $5,26 \%$. Hal ini menunjukkan bahwa rata-rata umur responden berada pada umur produktif dimana umur produktif seseorang dalam melaksanakan usahatani berkisar antara 15 tahun hingga 64 tahun.

b. Pendidikan Formal

Pendidikan merupakan salah satu aspek yang ikut menentukan kualitas Sumber Daya Manusia. Semakin tinggi pendidikan yang ditempuh maka semakin baik kualitas SDM. Pendidikan yang baik akan memudahkan petani dalam memahami dan menerapkan teknologi yang diterima. Distribusi responden berdasarkan Pendidikan Formal dan Non Formal yang pernah ditempuh dapat dilihat pada Tabel 5 .

Tabel 5. Distribusi Responden Berdasarkan Pendidikan Formal di Desa Sallu Kecamatan Miomaffo Barat Kabupaten Timor Tengah Utara, 2016.

\begin{tabular}{lcc}
\hline \multicolumn{1}{c}{ Tingkat Pendidikan } & Jumlah (Orang) & Persentase $(\%)$ \\
\hline SD & 66 & 69,47 \\
SMP & 24 & 25,26 \\
SMA & 5 & 5,27 \\
\hline Jumlah & 95 & 100 \\
\hline
\end{tabular}

Data Tabel 5. menunjukkan jumlah responden dengan tingkat Pendidikan SD sebanyak 66 orang $(69,47 \%)$, SMP sebanyak 24 orang $(25,26 \%)$, SMA sebanyak 5 orang $(5,27 \%)$. Hal ini menunjukkan bahwa sebagian besar petani memiliki pemahaman yang sangat rendah terhadap pemanfaatan teknologi bila ditinjau dari tingkat pendidikan. Namun petani memiliki pengalaman dan berbagai pendidikan non formal yang diperoleh dalam pengelolaan usahatani dengan memanfaatkan teknologi. Aktivitas usahatani selalu didampingi oleh penyuluh baik dari LSM maupun dari instansi pemerintah.

c. Pengalaman Usahatani Bawang Putih

Pengalaman dalam bekerja dapat menunjukkan seberapa besar seseorang memahami dan mengerti masalah yang ada dalam bidang pekerjaannya. 
Lamanya pengalaman bertani pada petani bawang putih di Kelurahan Sallu dapat dilihat pada Tabel 6 .

Tabel 6. Distribusi Responden Berdasarkan Pengalaman Usahatani di Desa Sallu Kecamatan Miomaffo Barat Kabupaten Timor Tengah Utara, 2016.

\begin{tabular}{lcc}
\hline \multicolumn{1}{c}{ Lama Kerja } & Jumlah (Orang) & Persentase $(\%)$ \\
\hline $0-10$ tahun & 13 & 13,69 \\
$11-20$ tahun & 32 & 33,68 \\
$\geq 20$ tahun & 50 & 52,63 \\
\hline Jumlah & 95 & 100 \\
\hline
\end{tabular}

Data Tabel 6. menunjukkan rata-rata pengalaman anggota kelompok tani dalam berusahatani bawang putih 22,1 tahun dengan kisaran terbanyak berada di atas 20 tahun yakni 50 orang dengan presentasinya 52,63\%, pengalaman terendah yakni $0-10$ tahun sebanyak 13 orang $13,69 \%$. Hal ini menunjukkan bahwa sebagian besar petani memiliki pengalaman yang cukup baik dalam berusahatani bawang putih. Hal ini dikarenakan faktor iklim yang mendukung serta pekerjaan berusahatani bawang putih sudah dilakukan secara turun-temurun sehingga menyebabkan pemahaman petani akan pengelolaan usahatani bawang putih cukup baik.

\section{d. Jumlah Anggota Keluarga}

Jumlah Anggota Keluarga juga dapat mempengaruhi motivasi petani dalam bekerja. Semakin banyak anggota keluarga maka semakin banyak tanggungan dan besarnya tanggung jawab yang harus ditanggung oleh kepala keluarga. Distribusi responden dapat dilihat pada Tabel 7.

Tabel 7. Distribusi Responden Berdasarkan Banyaknya Anggota Keluarga di Desa Sallu Kecamatan Miomaffo Barat Kabupaten Timor Tengah Utara, 2016.

\begin{tabular}{|c|c|c|}
\hline Banyaknya Tanggungan & Jumlah (Orang) & Persentase $(\%)$ \\
\hline $2-3$ & 27 & 28,42 \\
\hline $4-5$ & 58 & 61,05 \\
\hline$>5$ & 10 & 10,53 \\
\hline Jumlah & 95 & 100 \\
\hline
\end{tabular}

Tabel 7. menunjukkan bahwa rata-rata jumlah keluarga yang menjadi tanggungan keluarga terbanyak berada pada kisaran 4-5 orang sebanyak 58 orang atau $61,05 \%$ dari keseluruhan responden. Sedangkan tanggungan keluarga terendah berada pada kisaran di atas 5 orang yakni sebanyak 10 orang responden $(10,53 \%)$. Hal ini menunjukkan bahwa adanya tanggungan keluarga memerlukan tanggung jawab untuk menghidupi anggota keluarganya. Disisi lain juga banyaknya anggota keluarga menjadi suatu kekuatan tenaga kerja yang dimiliki dalam menyelesaikan usahatani bawang putih.

e. Luas Lahan Garapan

Besarnya lahan garapan usahatani bawang putih mempengaruhi besarnya pendapatan petani. Luas lahan garapan anggota kelompok dalam berusahatani bawang putih di Desa Sallu dapat dilihat pada Tabel 8 .

Tabel 8 Distribusi Responden Berdasarkan Luas Lahan Garapan di Desa Sallu, Kecamatan Miomaffo Barat Kabupaten Timor Tengah Utara, 2016.

\begin{tabular}{|c|c|c|}
\hline Luas Lahan (Are) & Jumlah (Orang) & Persentase $(\%)$ \\
\hline $1-5$ & 81 & 85,27 \\
\hline $6-10$ & 13 & 13,68 \\
\hline$>10$ & 1 & 1,05 \\
\hline Jumlah & 95 & 100 \\
\hline
\end{tabular}

Tabel 8. menunjukkan bahwa luasan lahan garapan petani responden di Desa Sallu dengan luasan rata-rata $1-5$ are yakni sebanyak 81 orang $(85,27 \%)$ sedangkan luasan lahan garapan tertinggi adalah sebanyak 12 are yakni sebanyak 1 orang petani dengan presentasinya $1,05 \%$. Hal ini menunjukkan bahwa luasan lahan garapan petani yang demikian dipengaruhi oleh kepemilikan lahan yang dimiliki oleh petani yang juga mempengaruhi produktivitas dari usahatani bawang putih yang dijalani. Lahan yang subur dan luas akan memotivasi petani usahatani bawang putih untuk meningkatkan kinerjanya secara efisien dan efektif.

\subsection{Keadaan Kelembagaan Kelompok Tani}

Jumlah kelompok tani di Desa Sallu sampai saat ini sebanyak 8 (delapan) kelompok tani, terbentuk dari tahun 2005 hingga ada yang tahun 2016 baru terbentuk (penambahan 2 kelompok tani) yang tergabung dalam 1 Gapoktan yakni Gapoktan Banu-Ola yang dibentuk pada tahun 2010. Jumlah anggota petani yang terdapat dalam Gapoktan tersebut adalah 141 orang dengan kelas kelompok tani pemula. Perkembangan kelompok tani dalam Desa Sallu selalu berfluktuasi keanggotaannya. Hal ini dapat di lihat pada Tabel 9. mengenai klasifikasi kelompok tani yang ada di Desa Sallu Kecamatan Miomaffo Barat Kabupaten TTU.

\begin{tabular}{llccc}
\multicolumn{6}{l}{ Tabel 9. Perkembangan Kelompok Tani di Desa Sallu Tahun 2016.} \\
\hline \multirow{2}{*}{ No } & $\begin{array}{c}\text { Kelompok } \\
\text { Tani }\end{array}$ & $\begin{array}{c}\text { Kelas } \\
\text { Kelompok tani }\end{array}$ & $\begin{array}{c}\text { Tahun } \\
\text { terbentuk }\end{array}$ & $\begin{array}{c}\text { Jumlah } \\
\text { Anggota }\end{array}$ \\
\hline 1 & Tafen'tob & Pemula & 2007 & 15 orang \\
2 & Oel'nasi & Pemula & 2008 & 16 orang \\
3 & Nek'ana & Pemula & 2008 & 14 orang \\
4 & Ai'nun & Pemula & 2007 & 15 orang \\
5 & Melati & Pemula & 2008 & 18 orang \\
6 & Monitabua & Pemula & 2008 & 17 orang \\
\hline Jumlah & & & 95 orang \\
\hline
\end{tabular}

Tabel 9. menunjukkan bahwa semua kelompok tani yang ada masih dalam kategori kelas pemula ini disebabkan rendahnya tingkat teknis dan permasalahan yang ada belum tertangani secara maksimal. Di samping itu belum aktif, taraf pembentukan kelompok tani masih awal, pimpinan formal belum aktif, dan kegiatan kelompok bersifat informatif. Artinya kelompok tani menyelenggarakan kerjasama usahatani sehamparan pimpinan formal belum menonjol secara maksimal.

\subsection{Gambaran Usahatani Bawang Putih}

a. Pemilihan Bibit Unggul

Berdasarkan hasil wawancara dengan responden, bahwa penerapan teknologi terutama dalam pemilihan bibit unggul tidak diterapkan karena kurang ketersediaan dana, persediaan bibit dari hasil panen sebelumnya, luasan areal usahatani bawang putih yang tidak membutuhkan penanganan teknologi terutama dalam hal pemilihan bibit unggul.

\section{b. Olah Tanah}

Lahan yang akan ditanami bawang putih perlu diolah dengan gembur, dihaluskan, dan dibuat bedengan. Hal ini perlu dibuat agar lahan tersebut dapat menjadi media tanam yang baik bagi tanaman bawang putih. Distribusi responden berdasarkan tingkat penerapan teknologi pengolahan lahan yang digunakan untuk berusahatani bawang putih di Desa Sallu menunjukkan bahwa penerapan teknologi terutama pada pengolahan lahan bagi petani responden ratarata yang berusahatani bawang putih lahannya diolah secara manual dan sederhana sesuai kemampuan yang dimiliki baik modalnya, tenaga, dan luas lahannya.

\section{c. Cara tanam}

Cara tanam dengan memperhatikan jarak tanam, pola baris dan lubang tanam juga mempengaruhi hasil yang akan diperoleh petani. Tingkat penerapan cara tanam yang baik oleh petani anggota kelompok di Desa Sallu tidak diterapkan karena luasan areal lahan yang diolah untuk mengusahakan bawang putih yang sedikit, kondisi tanah yang potensial untuk mengusahakan bawang putih walaupun dengan pengolahan lahan yang semi tradisional.

\section{d. Pemupukan}

Sejalan dengan peningkatan produksi, tentunya terjadi peningkatan pengangkatan unsur hara dari dalam tanah terutama pada saat dilakukan panen. Karena itulah, Pemupukan diperlukan guna menghindari pemiskinan unsur hara dalam lahan yang digunakan (Lamina, 1989). Penerapan teknologi pemupukan pada usahatani bawang putih tidak dilakukan karena menganggap lahan yang diusahakan masih mengandung humus tanah dan kurang ketersediaan modal dalam mengadakan pupuk.

\section{e. Penyiangan}

Penyiangan merupakan usaha untuk menanam kembali, mengurangi jumlah tanaman dan membersihkan areal lahan yang ditanam untuk menghindari persaingan dengan tujuan produktivitas tanaman tersebut dapat berlimpah. Tingkat penerapan teknologi terutama penyiangan berdasarkan hasil penelitian menunjukkan bahwa penyiangan pada tanaman bawang putih disesuaikan kondisi bawang pada saat pertumbuhannya. Apabila pertumbuhannya terganggu oleh banyaknya persaingan baik antar sesama tanaman bawang, antara tanaman dengan gulma serta bila tanaman bawang mati atau pertumbuhannya tidak baik maka perlu di sulam.

\section{f. Pengairan}

Pengairan bagi lahan pertanian bawang putih perlu diperhatikan terutama untuk lahan di lereng gunung yang tidak beririgasi. Penerapan teknik pengairan lahan pertanian bawang putih di Desa Sallu menunjukkan bahwa penerapan teknologi terutama pengairan pada lahan yang ditanami bawang putih tidak diterapkan karena semuanya dikembalikan pada kemurahan alam.

\section{g. Pengendalian HPT}

Pengendalian HPT dilaksanakan guna melindungi tanaman bawang putih untuk membatasi kehilangan hasil akibat adanya hama dan penyakit yang dapat merusak tanaman. Hal ini menunjukkan bahwa sebagian besar petani terkadang menerapkan teknologi pengendalian HPT bila dibutuhkan. Hal ini berarti bahwa bila hama yang mengganggu tanaman bawang putih mulai menyerang maka akan dilakukan pengendalian secara efektif. Namun bila dirasa oleh petani tidak ada hama yang mengganggu maka tidak dilakukan penerapan teknologi pengendalian HPT. 
h. Panen

Untuk memperoleh produksi dengan mutu yang baik, maka waktu dan terapan teknologi yang digunakan haruslah tepat. Demikian pula dengan kegiatan panen yang harus dilaksanakan pada tanaman yang memiliki ciri siap panen. Tingkat penerapan teknologi dalam hal pemanenan terkadang diterapkan oleh petani bila memungkinkan, artinya bahwa bila luasan areal tanam dalam jumlah yang luas maka perlu dilakukan penerapan teknologi pemanenan yang lebih efektif dan efisien. Namun karena luasan areal yang sedikit maka tidak dilakukannya teknologi pemanenan yang berarti.

\section{i. Pasca Panen}

Kegiatan yang dilaksanakan setelah kegiatan panen juga akan mempengaruhi hasil yang dipasarkan. Kegiatan yang dilaksanakan antara lain pengupasan, pembersihan, pengeringan, pemipilan, penyortiran dan penyimpanan. Presentasi penerapan teknologi pasca panen menunjukkan bahwa diterapkan secara tradisional bila dalam jumlah produksi yang relatif sedikit. Namun dalam jumlah yang banyak maka akan dilakukan proses pembersihan, pengeringan, pemipilan dan penyimpanan.

\subsection{Tingkat Partisipasi Anggota Kelompok Tani}

\section{a. Partisipasi pada Rapat Akhir Tahunan}

Kelompok tani merupakan salah satu organisasi yang tujuan dari adanya kelompok tani tersebut adalah sebagai wadah para anggota untuk saling bertukar informasi. Salah satunya adalah rapat akhir tahunan. Tujuan kegiatan dimaksud adalah peningkatan transparansi pengelolaan kelompok tani sehingga meminimalisir kesenjangan-kesenjangan yang terjadi serta meningkatkan pula keeratan hubungan kerja sama antar anggota kelompok.

Berdasarkan hasil penelitian, menunjukkan bahwa rapat anggota kelompok tani sering dilakukan tetapi kurang optimal. Hal ini kurang dinamis keeratan hubungan antar anggota kelompok tani. Disebabkan anggota kelompok tani kebanyakan bekerja sebagai petani yang berusaha di berbagai kegiatan baik sebagai peternak, kuli bangunan, aparat pemerintah desa. Sehingga selalu menjadi hambatan dalam setiap rapat yang akan diadakan.

\begin{tabular}{llccc}
\multicolumn{6}{l}{ Tabel } & 10. Partisipasi Anggota Kelompok Tani pada Rapat Akhir Tahunan. \\
\hline \multirow{2}{*}{ No } & $\begin{array}{c}\text { Kategori Partisipasi } \\
\text { Anggota }\end{array}$ & $\begin{array}{c}\text { Persentase Pencapaian } \\
\text { Skor }\end{array}$ & $\begin{array}{c}\text { Jumlah } \\
\text { (orang) }\end{array}$ & $\begin{array}{c}\text { Persentase } \\
(\%)\end{array}$ \\
\hline 1 & Sangat tidak aktif & $\geq 20-36$ & 0 & 0 \\
2 & Tidak aktif & $>36-52$ & 39 & 41,05 \\
3 & Ragu-ragu/kadang-kadang & $>52-68$ & 30 & 31,57 \\
4 & Aktif & $>68-84$ & 16 & 16,84 \\
5 & Sangat aktif & $>84-100$ & 10 & 10,54 \\
\hline Jumlah & & 95 & 100 \\
\hline
\end{tabular}

Data Tabel 10. menggambarkan bahwa partisipasi anggota kelompok tan dalam rapat akhir tahun dari 95 responden penelitian ini, terdapat 39 orang $(41,05 \%)$ anggota kelompok tani terbanyak berada dalam kategori tidak aktif mengikuti rapat akhir tahun dan 10 orang(10,54\%) anggota kelompok tani berada dalam kategori sangat aktif mengikuti rapat akhir tahun. Hal ini menunjukkan bahwa peran penyuluh penting dilakukan upaya pembinaan kesadaran anggota kelompok tani tentang manfaat RAT, selain itu memupuk persaudaraan, saling mengetahui perkembangan maju/mundurnya kelompok tani, serta mengevaluasi kegiatan kelompok tani yang sudah berjalan dalam satu tahun baik dari kegiatannya secara fisik dan non fisik.

\section{b. Partisipasi pada Pertemuan Rutin}

Partisipasi anggota dalam pertemuan rutin kegiatan usahatani bawang putih merupakan unsur yang memacu kegiatan dan untuk mempertahankan ikatan pemersatu di dalam kelompok tani tersebut. Pertemuan dan kegiatan merupakan dua hal yang saling berkaitan dan menunjang satu sama lain. Selain itu dapa membantu anggota untuk saling tukar informasi berkaitan usaha bawang putih yang dijalankan baik dari penyuluh, tentang pemasaran, maupun teknologi usahataninya.

\section{Tabel 11. Partisipasi Anggota Kelompok pada Pertemuan Rutin.}

\begin{tabular}{clccc}
\hline No & $\begin{array}{c}\text { Kategori Partisipasi } \\
\text { Anggota }\end{array}$ & $\begin{array}{c}\text { Persentase } \\
\text { Pencapaian Skor }\end{array}$ & $\begin{array}{c}\text { Jumlah } \\
\text { (orang) }\end{array}$ & $\begin{array}{c}\text { Persentase } \\
(\%)\end{array}$ \\
\hline 1 & Sangat tidak aktif & $\geq 20-36$ & 0 & 0 \\
2 & Tidak aktif & $>36-52$ & 0 & 0 \\
3 & Ragu-ragu/kadang-kadang & $>52-68$ & 40 & 42,11 \\
4 & Aktif & $>68-84$ & 28 & 29,47 \\
5 & Sangat aktif & $>84-100$ & 27 & 28,42 \\
\hline Jumlah & & 95 & 100 \\
\hline
\end{tabular}

Hasil penelitian menunjukkan bahwa partisipasi pada pertemuan dan kegiatan usahatani bawang putih tergolong sedang/ragu-ragu/kadang masih dalam kategori sedang disebabkan, karena kesibukan pribadi dan bekerja sebagai kerja harian lebih diutamakan oleh anggota kelompok tani. Hal ini disebabkan karena mayoritas masyarakat bekerja dibidang pertanian. Dan kurangnya tenaga PPL yang ada di Desa Sallu untuk membina kelompok tani. Dilain sisi didasari dengan kebiasaan masyarakat yang ada di Desa Sallu masih menganut tradisi yang turun temurun, sistem bertaninya masih tradisional karena dipengaruhi oleh tingkat pendidikan yang masih rendah. Sehingga menyebabkan tingkat sosialnya kelompok tani rendah untuk menerima inovasi-inovasi baru. Tingkat pendidikan yang lebih dominan adalah tamatan $\mathrm{SD}$, sehingga peran serta masyarakat yang ada atau kelompok tani dengan masalah partisipasi dalam kegiatan-kegiatan sosial di Desa Sallu masih dikatakan rendah. Kelembagaan petani belum berfungsi secara optimal, perhatian pemerintah Desa terhadap petani masih rendah. Sehingga perlu adanya impact point yang di laksanakan di Desa Sallu salah satunya adalah memberikan penyuluhan kepada kelompok tani dan GAPOKTAN tentang tupoksi dan manajemen kelompok, memberikan informasi tentang kelembagaan yang sinergis, dinamika kelompok tani, pengkaderisasi dan reorganisasi, dan melakukan pertemuan rutin dari PPL ke anggota kelompok tani.

\section{c. Partisipasi Pembuatan Program Penyuluhan}

Kelompok tani yang ada di lokasi penelitian cukup antusias dalam pembuatan programa penyuluhan, dengan dilihat antusias masyarakat atau kelompok tani dalam musyawarah bersama untuk membuat programa yang di ajukan ke penyuluh pertanian, dengan adanya usulan-usulan anggota kelompok pada saat membuat programa penyuluhan, seperti lebih meningkatkan kemampuan petani dalam mengelola tanaman bawang putih: memperbaiki sarana produksi, mengajukan pembuatan pelatihan dan pemasaran hasil yang optimal dalam berusahatani bawang putih. Namun sebagian kecil dari anggota kelompok tani yang mendukung dengan diketahui dari hasil analisis hasil yang diperoleh skor rata-rata tingkat partisipasi kelompok tani dalam pembuatan program penyuluhan pertanian dapat dilihat pada Tabel 12 .

Tabel 12. Partisipasi Anggota Kelompok Tani dalam Pembuatan Program Penyuluhan.

\begin{tabular}{llccc}
\hline No & $\begin{array}{c}\text { Kategori Partisipasi } \\
\text { Anggota }\end{array}$ & $\begin{array}{c}\text { Persentase } \\
\text { Pencapaian Skor }\end{array}$ & $\begin{array}{c}\text { Jumlah } \\
\text { (orang) }\end{array}$ & $\begin{array}{c}\text { Persentase } \\
(\%)\end{array}$ \\
\hline 1 & Sangat tidak aktif & $\geq 20-36$ & 3 & 3,15 \\
2 & Tidak aktif & $>36-52$ & 29 & 30,53 \\
3 & Ragu-ragu/kadang-kadang & $>52-68$ & 40 & 42,11 \\
4 Aktif & $>68-84$ & 22 & 23,16 \\
5 & Sangat aktif & $>84-100$ & 1 & 1,05 \\
\hline Jumlah & & 95 & 100 \\
\hline
\end{tabular}

d. Kinerja Anggota Kelompok dalam Akses Informasi

Gambaran mengenai tingkat kemampuan kinerja kelompok tani dari 95 responden yang diwawancarai, tingkat kemampuan kelompok tani tentang kinerja kelompok tani dalam akses informasi di Desa Sallu masih bersifat individual, sehingga tingkat kemampuan mereka sangat terbatas. Hal ini disebabkan karena faktor pendidikan dan sistem bertani yang masih bersifat tradisional.

\begin{tabular}{llccc}
\multicolumn{6}{l}{ Tabel } & 13. Kinerja Partisipasi Anggota dalam Akses Informasi. \\
\hline \multirow{2}{*}{ No } & $\begin{array}{c}\text { Kategori Partisipasi } \\
\text { Anggota }\end{array}$ & $\begin{array}{c}\text { Persentase } \\
\text { Pencapaian Skor }\end{array}$ & $\begin{array}{c}\text { Jumlah } \\
\text { (orang) }\end{array}$ & $\begin{array}{c}\text { Persentase } \\
(\%)\end{array}$ \\
\hline 1 & Sangat tidak aktif & $\geq 20-36$ & 0 & 0 \\
2 & Tidak aktif & $>36-52$ & 30 & 31,58 \\
3 & Kadang-kadang & $>52-68$ & 35 & 36,84 \\
4 & Aktif & $>68-84$ & 21 & 22,11 \\
5 & Sangat aktif & $>84-100$ & 9 & 9,47 \\
\hline Jumlah & & 95 & 100 \\
\hline
\end{tabular}

Tabel 13. menunjukkan bahwa kinerja anggota kelompok tani dalam berusahatani bawang putih yang dilakukan berada dalam kategori "Raguragu/kadang-kadang" yakni dari 95 responden yang diwawancarai 35 orang atau $35,84 \%$ mengatakan bahwa usahatani bawang putih ini kadang-kadang baru dilakukan karena terkadang kurang menguntungkan. Sedangkan 30 responden $(31,58 \%)$ tidak aktif menerapkan teknologi sistem usahatani bawang putih secara luas tetapi hanya sekedar memenuhi kebutuhan keluarga. Sedang 21 responden $(22,11 \%)$ sangat aktif. Hal ini menunjukkan bahwa anggota kelompok tani di Desa Sallu dalam hal mengakses informasi dalam berusahatani bawang putih sangat dipengaruhi oleh faktor pendidikan, modal usaha, dan pola usahataninya yang masih tradisional yang belum membutuhkan sentuhan teknologi.

\section{e. Partisipasi Anggota Kelompok Tani Secara Menyeluruh}

Penilaian anggota kelompok tani di Desa Sallu secara keseluruhan dalam berusahatani bawang putih, maka pencapaian skor pada tingkat partisipasi anggota kelompok dalam berusahatani bawang putih pada kategori tidak aktif yaitu sebesar $20 \%$, kadang-kadang 50, 53\% ., aktif 20\%, dan sangat aktif $9,47 \%$. Dan rata-rata anggota kelompok tani yang berusahatani bawang putih berada secara keseluruhan berada pada kategori kadang-kadang dengan bobot pencapaian 63,6 atau 3,18

Sesuai Tabel 14. penilaian responden berada pada kategori kadang-kadang baru berusahatani bawang putih yaitu sebesar 50,53\%, dengan bobot pencapaian nilai 63,6 . Hal ini menunjukkan bahwa para petani di lokasi penelitian dalam berusahatani bawang putih saat ini dilakukan dengan mempertimbangkan peluang harga, cuaca, dan informasi pasar sehingga masih berusahatani secara kecilan untuk memenuhi kebutuhan diri keluarga. 
Tabel 14. Partisipasi Anggota Kelompok Tani Secara Menyeluruh.

\begin{tabular}{llccc}
\hline No & $\begin{array}{c}\text { Kategori Partisipasi } \\
\text { Anggota Kelompok }\end{array}$ & $\begin{array}{c}\text { Persentase } \\
\text { Pencapaian Skor }\end{array}$ & Frekuensi & $\begin{array}{c}\text { Persentase } \\
(\%)\end{array}$ \\
\hline 1 Sangat tidak Aktif & $\geq 20-36$ & - & - \\
2 & Tidak Aktif & $>36-52$ & 19 & 20,00 \\
3 & Kadang & $>52-68$ & 48 & 50,53 \\
4 & Aktif & $>68-84$ & 19 & 20,00 \\
5 & Sangat Aktif & $>84-100$ & 9 & 9,47 \\
\hline Jumlah & & 95 & 100 \\
\hline
\end{tabular}

3.6 Kendala-Kendala yang Dihadapi Anggota Kelompok Tani

a. Kurang bibit bawang putih yang unggul

Keberhasilan usahatani bawang putih sangat ditunjang oleh faktor bibit karena produksinya tergantung dari mutu bibit yang digunakan. Umbi yang digunakan sebagai bibit harus bermutu tinggi, berasal dari tanaman yang pertumbuhannya normal, sehat, serta bebas dari hama. Menurut (Soekartawi, 1995) bahwa faktor bibit memegang peranan penting untuk menunjang keberhasilan produksi tanaman, selain itu juga penggunaan bibit yang bermutu tinggi merupakan langkah awal peningkatan produksi. Keberadaan bibit di lokasi penelitian diperoleh dari hasil tanaman sebelumnya yang dipilih menurut perkiraan petani. Hasil tanaman yang dijadikan bibit, dipilih kemudian diikat (aisat) dan dilakukan pengasapan agar tidak terjadi penyusutan. Kondisi ini menunjukkan bahwa bentuk pemilihan bibit yang dilakukan secara manual dan turun-temurun. Bila bibit tidak tersedia, dilakukan pembelian sesuai kemampuan modal petani. Hal ini akan berpengaruh pada luasnya lahan yang akan ditanami bawang putih.

\section{b. Akses informasi harga pasar hasil bawang putih}

Aspek informasi harga pasar hasil bawang putih merupakan masalah di luar usahatani yang perlu diperhatikan. Seperti kita ketahui petani di lokasi penelitian serba terbatas dan berada pada posisi yang lemah dalam penawaran persaingan, terutama yang menyangkut penjualan hasil dan pembelian bahan-bahan pertanian. Penentu harga produk tidak pada petani. Petani harus terpaksa menerima apa yang menjadi kehendak dari pembeli dan penjual. Makin petani maju, ketergantungan akan dunia luar akan semakin besar. Tengkulak memegang peranan yang besar pada aspek penjualan hasil usahatani bawang putih. Apabila diamati secara seksama permasalahan ini timbul karena: Jaringan informasi pasar masih sangat terbatas Belum adanya relevansi antara political will, political statement dan political action. Sumber daya manusia atau pelaksanaannya masih terbatas Sarana dan prasarana masih kurang memadai. Jenis data dan informasi yang dikumpulkan dan disebarkan belum mendorong terjadinya transaksi. Anggota kelompok tani masih rendah tingkat kesadarannya dalam melaksanakan kesepakatan dan keputusan kelompok, tingkat kehadiran anggota kelompok tani dalam pertemuan belum optimal dan tidak rutin. Mengakibatkan kemandirian petani/ kelompok tani yang ada di Desa Sallu dalam berusahatani masih rendah karena kelembagaan masih lemah. Pembagian tugas pengurus kelompok tani belum merata dan masih sangat tergantung kepada ketua. Kerjasama antara kelompok tani untuk melakukan usaha bersama dalam rangkah mendukung usahatani masih lemah, dan tingkat kesadaran kelompok tani dalam pemeliharaan jaringan informasi harga pasar bawang putih masih rendah.

\section{c. Pola usahatani bawang putih masih tradisional}

Sebagian besar petani / anggota kelompok tani dalam berusahatani bawang putih masih bersifat tradisional dengan modal, ketrampilan dan pengetahuan serta teknologi terbatas/rendah. Teknik pertanian yang dilakukan, lahan yang ditanam merupakan lahan yang dibersihkan atau di olah dari lahan sebelum yang telah ditanami dengan jenis tanaman lain. Setelah diolah (di bedeng seadanya) menunggu untuk musim hujan tiba sesuai perkiraan waktu petani baru ditanami, diberi pupuk seadanya dari jerami tanaman sebelumnya, pengairan tergantung pada musim hujan. Pemeliharaan dilakukan seadanya, biasanya dilepas beberapa saat, dibersihkan sambal menunggu untuk dipanen. Proses ini dilakukan secara turun-temurun dan menjadi rutinitas setiap tahun. Dengan demikian, kelompok tani di Desa Sallu belum menjadi kelompok solusi, sehingga tingkat kreativitas bertani belum terlihat.

\section{d. Belum dilakukan pelatihan budidaya bawang putih}

Pelatihan usahatani bawang putih merupakan proses pembelajaran yang melibatkan perolehan keahlian, konsep, peraturan, atau sikap untuk meningkatkan kinerja petani (Simamora, 2006). Menurut pasal 1 ayat 9 UndangUndang No.13 Tahun 2003, pelatihan kerja adalah keseluruhan kegiatan untuk memberi, memperoleh, meningkatkan, serta mengembangkan kompetensi kerja, produktivitas, disiplin, sikap, dan etos kerja pada tingkat ketrampilan dan keahlian tertentu sesuai dengan jenjang dan kualifikasi jabatan dan pekerjaan. Berkaitan dengan kondisi anggota kelompok usahatani bawang putih, sampai saat ini belum pernah dilakukan pelatihan usahatani bawang putih secara bersama penyuluh pertanian. Kondisi ini sebetulnya sangat membantu petani karena dengan adanya perubahan teknologi dan perubahan iklim mengakibatkan adanya perubahan cara dalam berusahatani secara baik dan benar di lokasi anggota kelompok.

\section{e. Iklim yang kurang bersahabat}

Secara teknis dalam budidaya tanaman bawang putih, hampir semua unsur iklim berpengaruh terhadap produksi dan pengelolaannya. Dan masing-masing lokasi penanaman bawang putih mempunyai pengaruh dan peran yang berbeda terhadap berbagai aspek dalam budidayanya. Iklim merupakan komponen ekosistem dan faktor produksi yang sangat dinamik dan sulit dikendalikan. Dalam praktik, iklim dan cuaca sangat sulit untuk dimodifikasi/ dikendalikan sesuai dengan kebutuhan, kalaupun bisa memerlukan biaya dan teknologi yang tinggi. Iklim/cuaca sering seakan-akan menjadi faktor pembatas produksi pertanian. Karena sifatnya yang dinamis, beragam dan terbuka, pendekatan terhadap cuaca/iklim agar lebih berdaya guna dalam bidang pertanian, diperlukan suatu pemahaman yang lebih akurat teradap karakteristik iklim melalui analisis dan interpretasi data iklim. Mutu hasil analisis dan interpretasi data iklim, selain ditentukan oleh metode analisis yang digunakan, juga sangat ditentukan oleh jumlah dan mutu data. Oleh karena itu, diperlukan koordinasi dan kerjasama yang baik antar instansi pengelola dan pengguna data iklim demi menunjang pembangunan pertanian secara keseluruhan.

\section{f. Lahan usaha bawang putih semakin sempit}

Lahan usahatani bawang putih di Desa Sallu semakin sempit sehingga luasan usahanya dianggap yang tidak menguntungkan. Sempitnya luasan lahan usahatani bawang putih ini akibat bertambahnya jumlah pendidik, pola usahatani tidak terbatas pada usahatani bawang putih tetapi sudah beragam komoditi yang diusahakan, dan hal ini akan membatasi petani berbuat pada rencana yang lebih lapang. Keadaan yang demikian akan membuat petani serba salah, bahkan menjurus kepada keputusasaan. Tanah yang sempit dengan kualitas tanah yang kurang baik akan menjadi beban bagi petani pengelola usaha tani bawang putih. Akibat lanjutan dari sempitnya luasan lahan usahatani adalah rendahnya tingkat pendapatan petani. Besarnya jumlah anggota yang akan menggunakan pendapatan yang sedikit tadi, akan berakibat rendahnya tingkat konsumsi. Dan ini berpengaruh terhadap produktivitas kerja dan kecerdasan anak, menurunnya kemampuan berinvestasi, dan upaya pemupukan modal. Oleh karena itu perlunya pelatihan cara bercocok tanam secara intensif dalam lahan sempit tersebut sehingga petani yang selalu berusahatani secara ekstensifikasi secara perlahan menerapkan sistem intensifikasi.

\section{g. Kurangnya modal usaha}

Langkanya permodalan untuk pembiayaan usahatani bawang putih diakibatkan oleh keterbatasan akses petani terhadap permodalan dan masih tingginya suku bunga usahatani. Permodalan merupakan salah satu faktor produksi penting dalam usaha pertanian. Namun, dalam operasional usahanya tidak semua petani memiliki modal yang cukup. Aksesibilitas petani terhadap sumber-sumber permodalan masih sangat terbatas, terutama bagi petani-petani yang menguasai lahan sempit yang merupakan komunitas terbesar dari masyarakat pedesaan. Dengan demikian, tidak jarang ditemui bahwa kekurangan biaya merupakan kendala yang menjadi penghambat bagi petani dalam mengelola dan mengembangkan usaha tani. Dengan terbatasnya modal, maka penyediaan fasilitas kerja berupa alat-alat usahatani bawang putih semakin sulit dipenuhi. Akibatnya intensitas penggunaan kerja menjadi semakin menurun. Ketergantungan keluarga akan modal menyebabkan petani terjerat sistem yang dapat merugikan diri sendiri dan keluarganya, seperti adanya sistem ijon, dsb. Oleh karena itu perlu dukungan pemerintah terhadap penyediaan modal dengan bunga pinjam berkategori dan syarat pinjam sederhana.

\section{Simpulan}

Karakteristik anggota kelompok tani usahatani bawang putih di Desa Sallu memiliki potensi yang layak dikembangkan produktivitasnya yakni umur, pendidikan formal, pengalaman usahatani bawang putih, jumlah anggota keluarga, luas lahan garapan, dan kelembagaan kelompok taninya. Hasil penelitian, dari 95 responden kelompok tani yang ada di Desa Sallu Kecamatan Miomaffo Barat Kabupaten TTU, bahwa tingkat partisipasi anggota kelompok tani dalam berusahatani bawang putih menunjukkan hasil dalam kategori 3 yakni "Kadang-kadang" dengan nilai skor rata-rata tingkat partisipasi kelompok tani dalam berusahatani bawang putih dari 5 indikator penilaian adalah 63,6. Kendala-kendala dalam berusahatani bawang putih di Desa Sallu adalah kurang bibit bawang putih yang unggul, akses informasi harga pasar, pola usahatani bawang putih masih tradisional, pelatihan budidaya bawang putih, iklim yang kurang bersahabat, lahan usaha bawang putih semakin sempit, dan kurangnya modal usaha.

\section{Pustaka}

Balck, J.A., Champion, D.J., 1992. Metode dan Masalah Penelitian Sosial. Penerjemah: E. Koeswara, Dira Salam, Alfin Ruzhendi. Bandung: PT. Uresco.

Ban, A.W. van den, 1999. Penyuluhan Pertanian. Kanisius.

BPS Kab. TTU, 2015. Timor Tengah Utara dalam Angka 2015. Kefamenanu: Badan Pusat Statistik Kabupaten TTU.

Ken Suratiyah, M., 2015. Ilmu Usaha Tani (Edisi Revisi). Jakarta: Penebar Swadaya Grup.

Lamina, 1989. Kedelai dan Pengolahannya. Jakarta: Simpleks.

Pemerintah Republik Indonesia, 2003. Undang-Undang Nomor 13 Tahun 2003 tentang Ketenagakerjaan. 
Simamora, H., 2006. Manajemen Sumber Daya Manusia, Edisi 2. Yogyakarta:

$$
\text { STIE YKPN. }
$$

Soekartawi, 1995. Analisis Usaha Tani. Jakarta: Universitas Indonesia Press.

Sugiyono. 2011. Metode Penelitian Bisnis. Bandung: Alfabeta. 